\title{
Histochemical Detection of Mannitol Oxidase in the Digestive Gland of Gastropods
}

\author{
Alexandre Lobo-da-Cunha ${ }^{1,2}$, Diogo Amaral-de-Carvalho ${ }^{1}$, Elsa Oliveira ${ }^{1}$, Ângela Alves ${ }^{1}$ and Gonçalo Calado ${ }^{3}$ \\ 1. Department of Microscopy, Institute of Biomedical Sciences (ICBAS), University of Porto, Portugal. \\ 2. Interdisciplinary Center of Marine and Environmental Research (CIIMAR), Porto, Portugal. \\ 3. Department of Life Sciences, Lusophone University of Humanities and Technology, Lisbon, Portugal.
}

Mannitol oxidase catalyses the oxidation of D-mannitol to produce the sugar mannose, releasing hydrogen peroxide. This enzyme was detected in the digestive gland and digestive tract of some herbivorous gastropods, suggesting a role in metabolization of mannitol contained in their foodstuff [1, 2, 3]. Mannitol is a 6 carbon polyalcohol present in algae, fungi and plants. Therefore, it seems that herbivorous gastropods get nutritional benefits from the ingestion of polyalcohols present in algae and plants due to enzymes that convert these compounds into sugars [1]. Cell fractionation studies revealed that in the digestive gland of terrestrial gastropods mannitol oxidase is associated with a special kind of tubules with a diameter of $40 \mathrm{~nm}$ [3]. But, so far, most studies about mannitol oxidase were performed with terrestrial gastropods.

To extend existing knowledge, this enzyme was investigated in the digestive gland of the marine gastropods Aplysia depilans, Bulla striata, Siphonaria pectinata and Onchidella celtica, as well as in the garden snail Cornu aspersum (=Helix aspersa) and the land slug Lehmannia valentiana. For histochemical location of mannitol oxidase digestive gland samples were frozen in liquid nitrogen. Cryostat sections $12 \mu \mathrm{m}$ thick on glass slides coated with APES were air dried for about 1 hour before being introduced in reaction medium. This medium adapted from previously published methods [1] contained $0.5 \mathrm{mg} / \mathrm{ml} \mathrm{3-3'-diaminobenzidine}$ (DAB), $0.25 \mathrm{mg} / \mathrm{ml}$ horseradish peroxidase $(50 \mathrm{U} / \mathrm{ml})$ and $50 \mathrm{mM}$ D-mannitol in $50 \mathrm{mM}$ phosphate buffer $\mathrm{pH}$ 7.5. Control sections were incubated in medium without mannitol. Sections were incubated for about 2 hours at $30^{\circ} \mathrm{C}$. Mannitol oxidase activity was also assessed by biochemical methods. For ultrastructural studies digestive gland samples were fixed with $2.5 \%$ glutaraldehyde and $4 \%$ formaldehyde in cacodylate buffer, postfixed with osmium tetroxide, dehydrated and embedded in Epon. In cryostat sections, digestive gland cells containing mannitol oxidase were stained brown due to DAB oxidation (Fig. 1 A-C).

In control sections reaction was not observed in digestive gland cells (Fig. 1 D), but in other tissues unspecific reactions can occur. Biochemical assays also showed that all these six herbivorous species contain mannitol oxidase in the digestive gland. Enzyme activity was lower in $B$. striata and $S$. pectinata, being much higher in $O$. celtica and L. valentiana, and presented an intermediate value in the digestive gland of $A$. depilans and $C$. aspersum. The tubular structures typically associated with mannitol oxidase [3] were found in digestive gland cells of $A$. depilans, B. striata, C. aspersum and $L$. valentiana (Fig. $1 \mathrm{E}-\mathrm{F}$ ). The tubules are located inside rough endoplasmic reticulum cisternae in $A$. depilans, while in B. striata, C. aspersum and L. valentiana they are found within smooth membrane cisternae (Fig. 1 E). On the other hand, in $S$. pectinata and $O$. celtica these tubules were not observed. Thus, at least in marine gastropods, mannitol oxidase is not always associated with intracisternal tubules even in species with a high mannitol oxidase activity such as $O$. celtica.

\section{References:}

[1] J.E. Vorhaben, D.D. Smith Jr. and J.W. Campbell, Journal of Experimental Biology 231 (1984) p. 157. [2] A. Lobo-da-Cunha, Tissue \& Cell 31 (1999) p. 8.

[3] A.T. Large, C.J.P. Jones and M.J. Connock, Protoplasma 175 (1993) p. 93. 

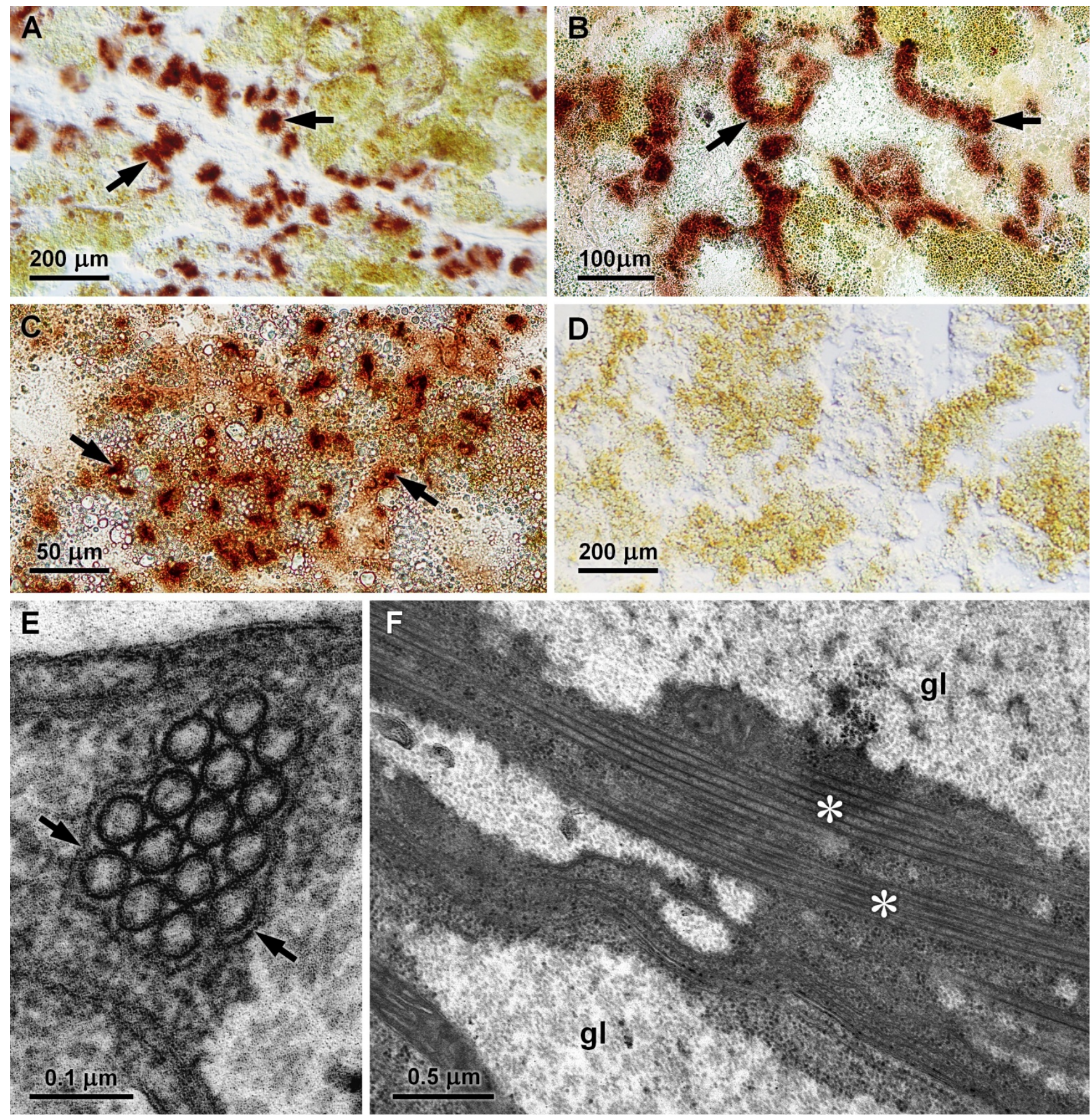

Figure 1. A. Histochemical detection of mannitol oxidase in digestive gland cells (arrows) of Aplysia depians. B. Mannitol oxidase reaction in digestive gland cells (arrows) of Siphonaria pectinata. C. Mannitol oxidase reaction (arrows) in the digestive gland of Cornu aspersum. D. Reaction is not observed in control sections incubated in medium without mannitol. E. Transverse sections of tubules inside a smooth membrane cisterna (arrows) in the digestive gland of Lehmannia valentiana. F. Tubules in longitudinal section (asterisks) associated with extensive glycogen deposits (gl) in the digestive cells of the digestive gland of L. valentiana. 